\title{
Energetic values and performace of broilers feeding sorghum and soybean meal based diets supplemented with $\beta$-glucanase and $\beta$-xylanase
}

\section{Valores energéticos e desempenho de frangos de corte alimentados com dietas a base de sorgo e farelo de soja suplementadas com $\beta$-glucanase and $\beta$-xylanase}

\author{
Evandro de Abreu Fernandes ${ }^{1 *}$; Maria Inês Homsi Brandeburgo ${ }^{2}$; \\ Carolina Magalhães Caires Carvalho ${ }^{3}$; Fernanda Heloisa Litz; \\ João Paulo Rodrigues Bueno'; Andre Lucas Silva Masculit; \\ Veridiana Aparecida Limão ${ }^{3}$ : Luciana Ruggeri Menezes Gotardo ${ }^{5}$
}

\begin{abstract}
Grains, brans, and vegetable meals may contain non-starch polysaccharides (NSP), which increases viscosity in the gastrointestinal tract (GIT) and interfere with the digestion and absorption of nutrients. This study aimed to evaluate the performance and determine the metabolizable energy of a sorghumbased broiler diet with and without the supplementation of an enzymatic complex. The experiments were conducted in a completely randomized design with 1200 chickens, using sorghum-based feed with and without the addition of $50 \mathrm{~g}$ of enzyme-CCE complex ( $\beta$-glucanase and $\beta$-xylanase), and with two levels of metabolizable energy $\left(\mathrm{ME} \mathrm{kg}{ }^{-1}\right)$ : ME; ME + CCE; reduced ME (-50 kcal kg-1); and reduced $\mathrm{ME}+\mathrm{CCE}$. The data were subjected to an analysis of variance and the means were compared using a Tukey's test at the 5\% significance level. At 42 and 47 days of age, the living weight of the birds fed with the reduced ME was low, while birds fed with reduced ME + CCE had the same weight as those fed with other energy diets (ME and ME + CCE). Feed conversion was poorest at 47 days of age for the birds on reduced ME diet. In the metabolic test (with fattening diets) to determine AME and AMEn, the reduced ME diet had the lowest result, confirming the effect of the addition of enzymes. The addition of CCE to sorghum-based diets provides enough enzymatic activity to increase the metabolizable energy of the diet (50 kcal of AME) and influence the growth performance of broilers at the slaughtering age.
\end{abstract}

Key words: Carbohydrases. Exoenzymes. Metabolizable energy. Poultry.

\footnotetext{
${ }^{1}$ Prof. Dr., Faculdade de Medicina Veterinária, FAMEV, Universidade Federal de Uberlândia, UFU, Uberlândia, MG, Brasil. E-mail: evandrof@umuarama.ufu.br

2 Prof ${ }^{a}$ Dr $^{\mathrm{a}}$, Instituto de Genética e Bioquímica, INGEB, UFU, Uberlândia, MG, Brasil. E-mail: homsibrandeburgo@yahoo.com.br

${ }^{3}$ Discentes do Curso de Doutorado em Ciências Veterinárias, FAMEV, UFU, Uberlândia, MG, Brasil. E-mail: carollcaires@ yahoo.com.br; fernandalitz@veterinaria.med.br; jprbueno@hotmail.com; verilimao@gmail.com

4 Discente do Curso de Graduação em Medicina Veterinária, FAMEV, UFU, Uberlândia, MG, Brasil. E-mail: andre.masculi@, hotmail.com

5 Discente do Curso de Mestrado em Ciências Veterinárias, FAMEV, UFU, Uberlândia, MG, Brasil. E-mail: luciana.ruggeri@ hotmail.com

* Author for correspondence
} 


\section{Resumo}

Grãos, farelos e farinhas de origem vegetal podem conter polissacarídeos não amiláceos (PNAs), que aumentam a viscosidade do trato grastro intestinal (TGI) e interferem na digestão e absorção de nutrientes. Objetivou-se avaliar o desempenho e determinar à energia metabolizável da dieta a base de sorgo, com e sem adição do complexo enzimático (CCE), para frangos de corte. Foram utilizados 1200 frangos de corte, distribuídos em delineamento inteiramente casualisado, alimentados com dois níveis de Energia Metabolizável (EM kg-1), em dietas à base de sorgo com ou sem a adição de $50 \mathrm{~g} \mathrm{de}$ completo enzimático ( $\beta$-glucanase e $\beta$-xylanase): Energia Metabolizável (EM); Energia Metabolizável com Complexo Enzimático (EM + CCE); EM reduzida (-50kcal EM $\left.\mathrm{kg}^{-1}\right)$ e EM reduzida + CCE. Os dados obtidos foram submetidos à análise de variância e as médias dos tratamentos em cada variável estudada foram comparadas entre si pelo Teste de Tukey a nível de 5\% de significância. Aos 42 e 47 dias de idade o peso vivo das aves alimentadas com EM reduzida foi menor, enquanto que EM reduzida + CCE apresentou peso igual ao das dietas EM e EM + CCE. A conversão alimentar aos 47 dias de idade na dieta EM reduzida apresentou o pior resultado. No teste metabólico, com as dietas de engorda, os valores de Energia Metabolizável Aparente (EMA) e Energia Metabolizável Aparente corrigida para nitrogênio (EMAn) foram menores na dieta com EM reduzida, comprovando o efeito da adição das enzimas. Concluiu-se que a adição de complexo enzimático ( $\beta$-glucanase and $\beta$-xylanase) melhora o desempenho de frangos de corte e aumenta a energia metabolizável aparente da dieta em $50 \mathrm{kcal}$.

Palavras-chave: Avicultura. Carboidrases. Energia metabolizável. Exoenzimas. Frangos.

\section{Introduction}

The extraordinary growth in the physical and economic productivity of broilers has been supported by a new generation of technology in the areas of genetics, ambience, nutrition, and poultry health. Broiler diets are prepared with $80-85 \%$ cereals, such as corn and sorghum, which are the main sources of energy, and with toasted soybean meal, which is the most important source of protein. Together, these cereals account for about $80 \%$ of the feed cost, and despite their importance, each of these ingredients is known to contain varying concentrations of anti-nutritional factors such as non-starch polysaccharides (NSP), phytate, tannin, protease inhibitors, and alpha-amylase inhibitors (CHOCT; HUGHES, 1999) that can adversely affected the digestive efficiency in animals.

Non-starch polysaccharides (NSPs) and lignin are the main components of dietary fiber (GDALA, 1998), while in cereals (KNUDSEN, 1997) there is an inverse relationship between the concentration of starch and dietary fibers. The main NSPs present in cereals are the $\beta$-glucans and pentosans (GUENTER, 2002), whose water-soluble fraction increases the viscosity of the fluids in the gastrointestinal tract, reducing enzyme-substrate interaction and impairing the bioavailability of nutrients. Exogenous enzymes may eliminate anti-nutritional factors in many foods, or increase the availability of glucose, proteins, and minerals enclosed in plants cell walls, or bind in a chemical form that the animal is unable to degrade (ROSSI; TEWIS, 2001).

The enzymatic activity of $\beta$-xylanase and $\beta$-glucanase has been evaluated in broiler diets that include different wheat cultivars, and they were found to improve the utilization of nutrients (nitrogen and dry matter) and metabolizable energy, and reduce viscosity (CHOCT et al., 1999; SALOBIR, 1998). The same results were observed in broiler diets that included barley (SALOBIR et al., 2000). Zanella et al. (1999), using corn-based diets with toasted or extruded soybean meal, concluded that enzyme supplementation improved body weight by $1.9 \%$ and the feed conversion rate by $2.2 \%$.

Oba et al. (2013), studying laying hens, showed that the addition of an enzyme complex to diets 
based on corn and soybean meal did not improve the birds' performance, eggshell and internal egg quality, dry matter and mineral content in the excreta, or microbiology of the contents of the small intestine. However, there was a significant linear increase in $\mathrm{pH}$ and a lower viscosity of digesta within the small intestine when levels of the enzyme complex were increased.

This study was conducted to evaluate the growth performance of broilers from one to 47 days old when fed diets based on sorghum and soybean meal that were supplemented with a commercial enzymatic complex ( $\beta$-glucanase and $\beta$-xylanase), and to determine the metabolizable energy of these diets.

\section{Material and Methods}

Our experiments were carried out at the Experimental Broiler Farm, Fazenda do Glória, Universidade Federal de Uberlândia in Uberlândia, Minas Gerais. The experimental shed was built on masonry, with a metal frame, an asbestos roof, side walls of wire mesh, a ceiling lined with a specific plastic used in poultry production, and sides protected with yellow curtains of the same plastic. The birds were placed in pens $(1.90 \times$ $1.50 \mathrm{~m}$ ) equipped with a bell drinkers and tubular feeder with a capacity of $25 \mathrm{~kg}$. In the early days, heating was carried out with infrared brooding, one for every four pens. During the rearing and completion stages, the house environment was controlled with the aid of ventilators and nebulizers via a thermostat and electronic control panel.

Birds of the Cobb-Vantress breed were raised from accommodation (one day old) until the age of slaughter (47 days old), and equal numbers of males (15) and females (15) were placed in each pen. The birds were reared throughout the experiment following the common rearing practices of research farms.
The experimental design was completely randomized, consisting of four treatments and ten replicates, for a total of 1200 birds. The treatments consisted of diets based on sorghum and soybean meal with four different metabolizable energy types: ME; ME + CCE; Reduced ME; and Reduced $\mathrm{ME}+\mathrm{CCE}$.

A commercial enzyme complex (Rovabio EXCEL $A P()$, originating from the fermentation process of Penicillium funiculosum and containing endo-1,4- $\beta$-xylanase $\left(22,000\right.$ pcs mistletoe $\mathrm{g}^{-1}$

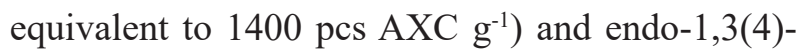
$\beta$-glucanase (2000 AGL units $\mathrm{g}^{-1}$ ), was added to the feed at a dose of $50 \mathrm{~g} \mathrm{t}^{-1}$, with the hypothesis that this amount will contribute $50 \mathrm{kcal}$ of AME $\mathrm{kg}^{-1}$ diet. The diets contained sorghum, soybean meal, degummed soybean oil, dicalcium phosphate, limestone, salt $(\mathrm{NaCl})$, vitamin and mineral premix, DL-methionine, and L-lysine (Table 1), and the feed was offered to the birds as follows: pre-starter phase $\left(0.300 \mathrm{~kg} \mathrm{bird}^{-1}\right)$, initial phase $\left(0.900 \mathrm{~kg}\right.$ bird $^{-}$ $\left.{ }^{1}\right)$, fattening phase $\left(2.500 \mathrm{~kg} \mathrm{bird}^{-1}\right)$, and slaughter phase (1.500 kg bird $\left.{ }^{-1}\right)$. During each phase, the feed and water were offered ad libitum, and the birds had a constant natural/artificial light program throughout the experiment.

To assess the performance traits (feed intake, body weight gain, and feed conversion), the birds and the leftover food were weighed weekly. Mortality and dead weight were recorded daily to calculate feasibility. Feed conversion was calculated based on the relationship between feed intake and liveweight, after accounting for the weight of dead birds.

In parallel with the performance study, an experiment was conducted to determine the apparent metabolizable energy (AME) and metabolizable energy corrected for nitrogen (AMEn) using 21 cages $(0.50 \times 0.50 \times 0.50 \mathrm{~m})$ equipped with a background of wire mesh and a metal tray. Four birds (two males and two females), 18 days of age and with the same body weight, were placed in each cage, and each cage was considered an experimental 
unit. Water and diets were renewed twice a day, and drinkers removed and washed in the morning and afternoon. Excreta were sampled in the morning and late in the day, and the samples were transferred to a small plastic bucket properly closed and numbered according to each cage. The design of the experiment was completely randomized, composed of four treatments and five repetitions, totaling 80 birds. The fattening diets used were the same as in the live performance experiment.

Table 1. Composition and nutritional levels of the experimental diets used in the following treatments: ME (A); ME + 50g CCE (B); reduced ME (C); reduced ME + 50g CCE (D).

\begin{tabular}{lcccccccc}
\hline \multicolumn{1}{c}{ Ingredients } & \multicolumn{2}{c}{ Pre-starter } & \multicolumn{2}{c}{ Initial } & \multicolumn{2}{c}{ Fattening } & \multicolumn{2}{c}{ Slaughter } \\
& A - B & C - D & A - B & C -D & A - B & C - D & A - B & C - D \\
\hline Sorghum 9.0\% & 55.32 & 56.44 & 56.58 & 57.70 & 61.77 & 62.89 & 63.89 & 65.06 \\
Soybean meal 46.5\% & 37.64 & 37.46 & 34.31 & 34.12 & 28.44 & 28.25 & 25.88 & 25.64 \\
Soybean oil & 3.122 & 2.189 & 5.108 & 4.176 & 5.856 & 4.924 & 6.670 & 5.730 \\
Limestone & 1.055 & 1.058 & 1.065 & 1.067 & 1.056 & 1.059 & 1.174 & 1.176 \\
Dicalcium phosphate & 1.763 & 1.760 & 1.798 & 1.794 & 1.676 & 1.673 & 1.308 & 1.305 \\
Salt & 0.462 & 0.462 & 0.450 & 0.450 & 0.450 & 0.450 & 0.450 & 0.450 \\
MC-Mix vit. adit. & $0.400^{1}$ & $0.400^{1}$ & $0.400^{1}$ & $0.400^{1}$ & $0.400^{2}$ & $0.400^{2}$ & $0.300^{3}$ & $0.300^{3}$ \\
MC-Mix mineral & 0.050 & 0.050 & 0.050 & 0.050 & 0.050 & 0.050 & 0.050 & 0.050 \\
DL-methionine & 0.093 & 0.092 & 0.098 & 0.097 & 0.127 & 0.126 & 0.135 & 0.135 \\
L-lysine HCl & 0.091 & 0.095 & 0.135 & 0.139 & 0.165 & 0.168 & 0.143 & 0.148 \\
Rovábio Excel (g ton ${ }^{-1}$ ) & $(\mathrm{B}) 50$ & $(\mathrm{D}) 50$ & $(\mathrm{~B}) 50$ & $(\mathrm{D}) 50$ & $(\mathrm{~B}) 50$ & $(\mathrm{D}) 50$ & $(\mathrm{~B}) 50$ & $(\mathrm{D}) 50$ \\
\hline Nutritional Levels & & & & & & & & \\
\hline ME (kcal kg-1) & 2960 & 2910 & 3100 & 3050 & 3200 & 3150 & 3280 & 3230 \\
Crude protein (\%) & 22.62 & 22.64 & 21.23 & 21.25 & 19.01 & 19.03 & 18.00 & 18.00 \\
Ether extract (\%) & 5.757 & 4.865 & 7.717 & 6.825 & 8.537 & 7.646 & 9.374 & 8.476 \\
Crude fiber (\%) & 4.396 & 4.416 & 4.191 & 4.211 & 3.921 & 3.940 & 3.798 & 3.816 \\
Calcium (\%) & 0.950 & 0.950 & 0.950 & 0.950 & 0.900 & 0.900 & 0.850 & 0.850 \\
Available phosphorous(\%) & 0.450 & 0.450 & 0.450 & 0.450 & 0.420 & 0.420 & 0.350 & 0.350 \\
Sodium (\%) & 0.200 & 0.200 & 0.195 & 0.195 & 0.196 & 0.196 & 0196 & 0196 \\
Digest. met. (\%) & 0.563 & 0.563 & 0.551 & 0.551 & 0.537 & 0.537 & 0.469 & 0.469 \\
Digestible lysine (\%) & 1.150 & 1.150 & 1.100 & 1.100 & 0.980 & 0.980 & 0.900 & 0.900 \\
Digest. threonine (\%) & 0.750 & 0.750 & 0.700 & 0.700 & 0.620 & 0.620 & 0.584 & 0.584 \\
Digest. tryptophan(\%) & 0.239 & 0.239 & 0.223 & 0.223 & 0.198 & 0.198 & 0.186 & 0.186 \\
\hline
\end{tabular}

${ }^{1}$ MC-Mix Starter 4 kg (composition per kilogram of feed): VitA 11.000 IU; D3 2.000 IU; E 16 mg; Folic Acid 400 mcg; Calcium Pantothenate 10 mg; Biotin $60 \mu \mathrm{g}$; Niacin 35 mg; Pyridoxine $2 \mathrm{mg}$; Riboflavin $4.5 \mathrm{mg}$; Thiamine $1.2 \mathrm{mg}$; B12 16 g; K $1.5 \mathrm{mg}$; Methionine $1.6 \mathrm{~g}$; Growth Promoter $384 \mathrm{mg}$; Coccidiostat $375 \mathrm{mg}$; Antioxidant $120 \mathrm{mg}$.

${ }^{2}$ MC-Mix Growing 4 kg (composition per kilogram of feed): VitA 9.000 IU; D3 1.600 IU; E 14 mg; Folic Acid 300 mg; Calcium Pantothenate $9 \mathrm{mg}$; Biotin $50 \mu \mathrm{g}$; Niacin $30 \mathrm{mg}$; Pyridoxine $1.8 \mathrm{mg}$; Riboflavin $4 \mathrm{mg}$; Thiamine $1 \mathrm{mg}$; B12 $12 \mu \mathrm{g}$; K3 1.5 mg; Choline $219 \mathrm{mg}$; Methionine $154 \mathrm{~g}$; Promoter $385 \mathrm{mg}$; Coccidiostat $550 \mathrm{mg}$; Antioxidant $120 \mathrm{mg}$.

${ }^{3}$ MC-Mix Finishing $3 \mathrm{~kg}$ (composition per kilogram of feed): VitA 2.700 IU; D3 450 IU; E 4.5 mg; Calcium Pantothenate 3.6 mg; Biotin $13.5 \mu \mathrm{g}$; Niacin 4.5 mg; Pyridoxine $360 \mu \mathrm{g}$; Riboflavin $900 \mu \mathrm{g}$; Thiamine $270 \mu \mathrm{g}$; B12 $2.7 \mu \mathrm{g}$; K3 $450 \mu \mathrm{g}$; Se 180 g; Methionine $906 \mathrm{mg}$; Antioxidant $120 \mathrm{mg}$.

${ }^{4} \mathrm{MC}-$ Mix Mineral $0.5 \mathrm{~kg}$ (guaranteed levels per kilogram of product): $\mathrm{Cu} 9 \mathrm{mg}$; Zn $60 \mathrm{mg}$; I $1 \mathrm{mg}$; Fe $30 \mathrm{mg}$; Mn $60 \mathrm{mg}$. 
The metabolic test was based on the total collection method of excreta (SIBBALD; SLINGER, 1963) for chickens aged 18 to 25 days, using the same animals as in the performance trial; therefore, only three days of adaptation to experimental diets and the new environment were needed, and five days for excreta collection. At the end of the experiment, feed intake of each experimental unit was calculated and the excreta were weighed. Homogenized excreta samples were placed in a circulating air oven at 55 ${ }^{\circ} \mathrm{C}$ for preliminary drying and later were subjected to physical and chemical analysis to determine dry matter \% (DM), nitrogen content (\%), ether extract $\%$ (EE), and gross energy ( $\mathrm{kcal} \mathrm{kg}^{-1}$ ) (BRASIL,
2009). Apparent metabolizable energy and AMEn were measured following Matterson et al. (1965).

The data were subjected to an analysis of variance (ANOVA) and the means were compared by the Tukey's test at a 5\% significance level using the statistical program ESTAT (ESTAT - System for Statistical Analysis, version 2.0, Department of Physical Sciences, FCAV, UNESP, Jaboticabal, SP).

\section{Results}

At 42 days, the effect of adding enzymes to the diet during the rearing period can be observed, as shown in Table 2.

Table 2. Effect of $\beta$-xylanase and $\beta$-glucanase on the performance of broilers at 42 days of age.

\begin{tabular}{ccccc}
\hline Treatment & $\begin{array}{c}\text { Feed Intake } \\
(\mathbf{k g})\end{array}$ & $\begin{array}{c}\text { Body Weight } \\
(\mathbf{k g})\end{array}$ & Feed Conversion & $\begin{array}{c}\text { Feasibility } \\
\mathbf{( \% )}\end{array}$ \\
\hline ME & 4.482 & $2.519 \mathrm{a}$ & 1.78 & 94.99 \\
ME + CCE & 4.497 & $2.512 \mathrm{a}$ & 1.80 & 94.02 \\
Reduced ME & 4.466 & $2.436 \mathrm{~b}$ & 1.84 & 94.88 \\
Reduced ME + CCE & 4.592 & $2.527 \mathrm{a}$ & 1.82 & 93.67 \\
\hline CV & 4.72 & 2.31 & 4.18 & 4.60 \\
SE & 0.067 & 0.018 & 0.024 & 1.374 \\
P value & 0.092 & 0.035 & 0.074 & 0.137 \\
\hline
\end{tabular}

The means with different letters are significantly different by Tukey's test with $\mathrm{P}<0.05$.

$\mathrm{CV}$ : coefficient of variation; $\mathrm{SE}$ : standard error.

Feed intake was not affected by dietary energy levels, including diets made with lower energy concentrations (reduced ME), just as there was no effect from the added enzymes in the $\mathrm{ME}+\mathrm{CCE}$ or reduced $\mathrm{ME}+\mathrm{CCE}$ treatments $(\mathrm{P}=0.09)$. The average body weight at 42 days was low $(\mathrm{P}=0.03)$, when the treatment consisted of a diet with 50 kcal reduced $M E \mathrm{~kg}^{-1}$ (reduced ME). No effect of $\beta$-xylanase and $\beta$-glucanase on the average weight was observed when the enzymes were added to diets with higher energy content (ME + CCE), but in the diets with reduced $\mathrm{ME}+\mathrm{CCE}$, where the energy content was lower, body weight was significantly higher, matching the results of the higher energy diet $(\mathrm{ME})$. Feed conversion $(\mathrm{P}=0.07)$ and feasibility ( $\mathrm{P}$ $=0.137$ ) were not affected by the treatments.

At 47 days of age, feed intake was not influenced $(\mathrm{P}=0.117)$ by the energy levels in diets formulated with $\mathrm{ME}$ and reduced $\mathrm{ME}$, nor when enzymes were added (ME + CCE and reduced $\mathrm{ME}+\mathrm{CCE}$ diets) (Table 3). The average body weight of broilers at 47 days of age was significantly lower $(\mathrm{P}=0.04)$ when the feed offered throughout their growth contained $50 \mathrm{kcal}$ less $\mathrm{ME} \mathrm{kg}{ }^{-1}$ (reduced ME) than in the treatments with $\mathrm{ME}$ and $\mathrm{ME}+\mathrm{CCE}$, or the treatments with 
reduced $\mathrm{ME}+\mathrm{CCE}$, where the enzyme complex was added to the least-energy diets. The addition of $\beta$-xylanase and $\beta$-glucanase enzymes did not increase body weight when added to diets with higher energy content (ME $+\mathrm{CCE})$. With addition of the enzymes, however, the reduced $\mathrm{ME}+\mathrm{CCE}$ treatment, in which the energy content was lower (ME less $50 \mathrm{kcal} \mathrm{kg}^{-1}$ ), resulted in a weight gain that was significantly higher than that seen with unsupplemented feed, equaling the results from $\mathrm{ME}$ and $\mathrm{ME}+\mathrm{CCE}$.

Feed conversion in the reduced ME treatment was significantly worse $(\mathrm{P}=0.037)$ than in other treatments, but the reduced $\mathrm{ME}$ treatment + CCE, with the enzyme addition, resulted in a feed conversion rate equal to the $\mathrm{ME}$ with and without enzyme treatments. Feasibility showed no differences between treatments $(\mathrm{P}=0.125)$

Table 3. Effect of $\beta$-xylanase and $\beta$-glucanase on the performance of broilers at 47 days of age.

\begin{tabular}{ccccc}
\hline Treatment & $\begin{array}{c}\text { Feed Intake } \\
(\mathbf{k g})\end{array}$ & $\begin{array}{c}\text { Average Body Weight } \\
(\mathbf{k g})\end{array}$ & Feed Conversion & $\begin{array}{c}\text { Feasibility } \\
(\mathbf{\%})\end{array}$ \\
\hline ME & 5.307 & $2.866 \mathrm{ab}$ & $1.84 \mathrm{~b}$ & 93.68 \\
ME + CCE & 5.223 & $2.894 \mathrm{a}$ & $1.80 \mathrm{~b}$ & 93.34 \\
Reduced ME & 5.453 & $2.805 \mathrm{~b}$ & $1.95 \mathrm{a}$ & 93.87 \\
Reduced ME + CCE & 5.433 & $2.913 \mathrm{a}$ & $1.86 \mathrm{~b}$ & 93.00 \\
\hline CV & 4.19 & 2.51 & 3.10 & 4.30 \\
SE & 0.071 & 0.023 & 0.018 & 1.278 \\
P value & 0.117 & 0.040 & 0.037 & 0.125 \\
\hline
\end{tabular}

The means with different letters are significantly different by Tukey's test with $\mathrm{P}<0.05$.

$\mathrm{CV}$ : coefficient of variation; SE: standard error.

The ME and ME + CCE diets were formulated to contain the same amount of energy, and the addition of $\beta$-xylanase and $\beta$-glucanase did not result in an increase in energy digestibility, resulting in similar AME values.

The diets of the reduced ME treatment were formulated to contain approximately $50 \mathrm{Kcal} \mathrm{ME}$ $\mathrm{kg}^{-1}$ less than the ME treatments. The values of apparent metabolizable energy (AME) $(\mathrm{P}=0.042)$ and AMEn $(\mathrm{P}=0.038)$ found in this experiment were significantly different between the $\mathrm{ME}$ and reduced $\mathrm{ME}$ : the absolute differences found for AME were $73 \mathrm{kcal} \mathrm{kg}^{-1}$ and for AMEn were $79 \mathrm{kcal} /$ $\mathrm{kg}$ (Table 4).
Table 4. Effect of addition of $\beta$-xylanase and $\beta$-glucanase on the value of apparent metabolizable energy (AME) and apparent metabolizable energy corrected for nitrogen (AMEn) in broiler fattening feed.

\begin{tabular}{ccc}
\hline Treatment & $\begin{array}{c}\text { AME } \\
\left(\mathbf{k c a l ~}_{\mathbf{~ k g}} \mathbf{- 1}\right)\end{array}$ & $\begin{array}{c}\text { AMEn } \\
\left(\mathbf{k c a l ~}_{\mathbf{~ k g}} \mathbf{- 1}\right)\end{array}$ \\
\hline ME & $3.457 \mathrm{a}$ & $3.254 \mathrm{a}$ \\
ME + CCE & $3.497 \mathrm{a}$ & $3.276 \mathrm{a}$ \\
Reduced ME & $3.384 \mathrm{~b}$ & $3.175 \mathrm{~b}$ \\
Reduced ME + CCE & $3.483 \mathrm{a}$ & $3.296 \mathrm{a}$ \\
\hline CV & 1.47 & 1.78 \\
SE & 0.067 & 0.084 \\
P value & 0.042 & 0.038 \\
\hline
\end{tabular}

The means with different letters are significantly different by Tukey's test with $\mathrm{P}<0.05$.

$\mathrm{CV}$ : coefficient of variation; $\mathrm{SE}$ : standard error. 


\section{Discussion}

In both age groups, 42 and 47 days, feed intake was not influenced by the energy value of the diets, nor by the addition of enzymes to the diets. The reduced ME diet was formulated to have a lower energy content of $50 \mathrm{kcal}$ compared with the ME diet, and this energy difference (apparent metabolizable energy and AMEn) was confirmed in the metabolic test with fattening feed.

The results show that the energy reduction was not enough to affect feed intake. According to Leeson (1999), reducing the energy level of diets usually leads to increased feed intake and poorer feed conversion, probably because the birds start to eat more in order to maintain their daily level of energy intake. However, this study showed that the use of $\beta$-glucanase and $\beta$-xylanase corrected the energy level of the reduced diets, making it unnecessary for the birds to consume more food to offset their nutritional requirements.

The reduced ME treatment was formulated to contain $50 \mathrm{kcal}$ less than the ME treatment, while the enzyme supplementation (reduced ME + CCE) was provided to cover for this difference. The body weight results obtained for both ages show that this hypothesis was confirmed. Furthermore, when comparing the results of the metabolism assay performed with fattening feed, this conclusion is again supported when the apparent metabolizable energy and AMEn values were found to be similar to those from $\mathrm{ME}$ and reduced $\mathrm{ME}+\mathrm{CCE}$, and smaller than the values for the reduced ME diet. The reduced ME + CCE treatment, on the other hand, had AME and AMEn values similar to those obtained in the assay for the ME diet with and without the addition of enzymes, indicating that the enzyme complex promoted the recovery of the energy value of the diet.

Comparing the absolute results for AME and AMEn from the fattening diet with reduced ME (3384 and 3175), with those from the reduced ME + CCE diet (3483 and 3296), it appears that there was an increase of $2.92 \%$ and $3.81 \%$ in dietary energy content, respectively. Fernandes et al. (2007) evaluated the metabolizable energy and digestibility of broiler feed supplemented with an enzyme complex based on amylase, protease, and xylanase in corn and sorghum diets, where the energy value of the food matrix, in the feed formulation software, was increased by $130 \mathrm{kcal} / \mathrm{kg}$, and they observed that the values of metabolizable energy, metabolizable energy corrected for nitrogen, protein, and fat digestibility were similar to the control treatment for grains. Leite et al. (2011) demonstrated that an enzymatic complex based on amylase, protease, pectinase, $\beta$-glucanase, pentosanase, cellulose, and phytase in added to sorghum diets provided better digestibility of fat, nitrogen, metabolizable energy, and dry matter.

A reduction in body weight on the reduced $\mathrm{ME}$ $+\mathrm{CCE}$ treatment in the two age groups, similar to that on the ME diet, demonstrates that the inclusion of enzymes in a diet based on sorghum and soybean meal increases its energy value. This finding coincides with the results reported by Zanella et al. (1999), who observed a gain of $1.9 \%$ in body weight on a diet of corn and soybean.

Yu and Chung (2004) compared the results from broilers fed diets with low and high energy levels, and concluded that weight gains were similar between treatments due to supplementation of the less energetic diets with amylase, xylanase, and protease, which demonstrates the effectiveness of these products with corn and soybean meal ingredients.

Similar results were found by Cuevas et al. (2002), who assessed the addition of xylanase, amylase, and protease to sorghum and soybeanbased diets with normal nutrient levels and with reduced levels (minus 3\%) of crude protein and metabolizable energy. They found, in broilers at 49 days of age, that feed intake and feed conversion improved significantly with the addition of enzymes to the two diets. Opalinsk et al. (2006) showed 
that supplementation with an enzyme complex (xylanase, glucanase, mannanase, pectinase, and protease) in chickens fed with corn, soybean meal, and disabled integral soybean with normal levels of nutrients, increased feed intake by $3 \%$ and weight gain by $2.5 \%$ compared to a diet without such supplementation.

Broilers fed with the ME + CCE diet had similar body weights compared to the birds fed with ME, demonstrating that the enzymatic complex had no significant effect. Possibly the energy levels of the ME treatment were sufficient for maximum response from those broilers, and were not influenced by the possible energy increase. These findings are in line with those of Sims et al. (2001), who demonstrated that the addition of enzymes to high-energy diets did not influence performance traits.

At 42 days of age there was no difference between treatments in feed conversion $(\mathrm{P}=0.07)$, while at 47 days of age it was found that chickens fed reduced ME diets had significantly lower feed conversion than birds that received other treatments. Feed conversion with reduced $\mathrm{ME}+\mathrm{CCE}$ diets was similar to that with the ME diet, and this leaves no doubt that enzymatic complex supplementation of lower-energy diets released nutrients, in sufficient concentrations, for the birds to achieve a performance equal to those fed higher-energy diets. This result appears to agree with the findings of Zanella et al. (1999) who observed a feed conversion gain of $2.2 \%$ in a diet based on corn and soybean meal. In addition, a number of authors including Ouhida et al. (2000), studying diets of corn, barley, and wheat; Daenicke et al. (2000) studying rye diets containing a mixture of beef tallow and soybean oil; Iji et al. (2001) studying a variety of low energy wheat diets; and Sims et al. (2001) studying a diet of maize, soybean flour, and poultry products, all found that the addition of exoenzymes containing $\beta$-glucanase and $\beta$-xylanase significantly improved the feed conversion of chickens at slaughter age. The calculated values in the metabolism test for the fattening diet were a real contribution of $99 \mathrm{kcal}$ of apparent metabolizable energy $\mathrm{kg}^{-1}$, or $121 \mathrm{kcal}$ of AMEn kg-1, confirming the results.

It is worth highlighting that, although most of these studies have used corn as the main energy source and the diets of our study were made with sorghum, there is nevertheless a great similarity between these two nutritious grains, a fact well demonstrated by Bornstein and Bartov (1967) and Diniz et al. (2002), and this makes comparisons with earlier studies appropriate.

\section{Conclusions}

The addition of the enzyme complex demonstrated that enzymatic activity in diets based on sorghum and soybean meal was sufficient to influence the performance of broiler chickens to 47 days. The addition of the enzyme complex enhanced the enzymatic digestion process in the gastrointestinal tract, resulting in an increase of at

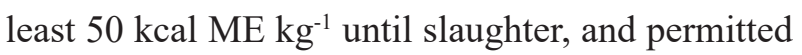
the preparation of a diet with lower energy content. In the fattening diet, the contribution of the enzyme complex to the digestive process was $99 \mathrm{kcal}$ of apparent metabolizable energy $\mathrm{kg}^{-1}$ and $121 \mathrm{kcal}$ of AMEn $\mathrm{kg}^{-1}$.

\section{References}

BORNSTEIN, S.; BARTOV, I. Comparisons of sorghum grain (milo) and maize as the principal cereal grain source in poultry rations: 2 . Their relative feeding value for layers 1. British Poultry Science, London, v. 8, n. 3, p. 223-230, 1967.

BRASIL. Ministério da Agricultura e Abastecimento. Sindicato Nacional da Indústria de Alimentação Animal. Associação Nacional dos Fabricantes de Rações. Compêndio brasileiro de alimentação animal. São Paulo: ANFAR/CBNA/SDR, 2009. 204 p.

CHOCT, M.; HUGHES, R. J. Chemical and physical characteristics of grain related to variability in energy and amino acid availability in poultry. Australian Journal of Agricultural Research, Victoria, v. 50, n. 5, p. 689-702, 1999. 
CHOCT, M.; HUGHES, R. J.; BEDFORD, M. R. Effects of a xylanase on individual bird variation, starch digestion throughout the intestine, and ileal and caecal volatile fatty acid production in chickens fed wheat. British Poultry Science, London, v. 40, n. 3, p. 419-422, 1999.

CUEVAS, A. C.; SAliNAS, R. A.; GONZÁlES, E. A. La utilizacion de enzimas como aditivos en dietas para pollos de engorda. Veterinaria Mexico, Cidade do México, v. 33, n. 1, p. 1-9, 2002.

DAENICKE, S.; JEROCH, H.; BOETTCHER, W.; SIMON, O. Interactions between dietary fat type and enzyme supplementation in broiler diets with high pentosan contents: effects on precaecal and total tract digestibility of fatty acids, metabolizability of gross energy, digesta viscosity and weights of small intestine. Animal Feed Science and Technology, Amsterdam, v. 84, n. 3, p. 279-294, 2000.

DINIZ, F. V.; FERNANDES, E. A.; MUNDIM, S. A. P.; ALVES, M. B. R.; AQUINO, C. A. M.; CHIARELI, D. Desempenho de frangos de corte submetidos a dietas formuladas a base de milho e sorgo. In: CONFERÊNCIA APINCO DE CIÊNCIA E TECNOLOGIA AVÍCOLA, 2002, Campinas. Anais... Campinas: Revista Brasileira de Ciência Avícola, 2002. p. 60. Suplemento 4.

FERNANDES, E. A.; MOREIRA, F. S.; MOREIRA, G. A.; ALMEIDA, R. A. T. Efeito da suplementação enzimática sobre a digestibilidade de nutrientes e energia metabolizável das rações à base de milho e à base de sorgo para frangos de corte. In: CONFERÊNCIA APINCO DE CIÊNCIA E TECNOLOGIA AVÍCOLA, 2007, Santos. Anais... Santos: Revista Brasileira de Ciência Avícola, 2007. p. 76. Suplemento 9.

GDALA, J. Composition, properties and nutritive value of dietary fibre of legume seeds. A review. Journal of Animal and Feed Sciences, Jablonna, v. 7, n. 2, p. 131149, 1998.

GUENTER, W. Practical experience with the use of enzymes. [S.1: s.n.], 2002. Available at: $<$ http://www.idrc. ca/en/ev-30924- 01-1-DO_TOPIC $>$. Accessed at: 3 aug. 2012 .

IJI, P. A.; HUGHES, R. J.; CHOCT, M.; TIVEY, D. R. Intestinal structure and function of broiler chickens on wheat-based diets supplemented with a microbial enzyme. Asian-Australasian Journal of Animal Sciences, Seoul, v. 14, n. 1, p. 54-60, 2001.

KNUDSEN, K. E. B. Carbohydrate and lignin contents of plant materials used in animal feeding. Animal Feed Science and Technology, Amsterdam, v. 67, n. 4, p. 319338, 1997.
LEESON, S. Enzimas para aves. In: SIMPÓSIO INTERNACIONAL SOBRE NUTRIÇÃO DE AVES, 1999, Campinas. Anais... Campinas: Fundação Apinco de Ciência e Tecnologia Avícolas, 1999. p. 173-185.

LEITE, P. R. S. C.; LEANDRO, N. S. M.; STRINGHINI, J. H.; CAFÉ, M. B.; GOMES, N. A.; JARDIM FILHO, R. M. Desempenho de frangos de corte e digestibilidade de rações com sorgo ou milheto e complexo enzimático. Pesquisa Agropecuária Brasileira, Brasília, v. 46, n. 3, p. 280-286, 2011.

MATTERSON, L. D.; POTTER, L. M.; STUTZ, M. W.; SINGSEN, E. P. The metabolizable energy of feed ingredients for chickens. Storrs, Connecticut: The University of Connecticut, Agricultural Experiment Station, 1965. $11 \mathrm{p}$.

OBA, A.; PINHEIRO, J. W.; SILVA, C. A.; CASTROGOMEZ, R. J. H.; BENITEZ, C. R.; UENO, F. K.; BORGES, C. A.; ALMEIDA, M. Características produtivas, qualitativas e microbiológicas de galinhas poedeiras alimentadas com diferentes níveis de complexo enzimático. Semina: Ciências Agrárias, Londrina, v. 34, n. 6, p. 4179-4186, 2013. Suplemento 2.

OPALINSK, M.; MAIORKA, A.; CUNHA, F.; SILVA, E. C. M.; BORGES, S. A. Adição de níveis crescentes de complexo enzimático em rações com soja integral desativada para frangos de corte. Archives of Veterinary Science, Curitiba, v. 11, n. 3, p. 31-35, 2006.

OUHIDA, I.; PEREZ, J. F.; GASA, J.; PUCHAL, F. Enzyme (beta-glucanase and arabinoxylanase) and/or sepiolite supplementation and nutritive value of maizebarley-wheat based diets for broiler chickens. British Poultry Science, London, v. 41, n. 5, p. 617-624, 2000.

ROSSI, F.; THEWIS, A. Enzymes in animal feed. Mededelingen van de Faculteit Landbouwwetenschappen Rijksuniversiteit Gent, Gent, v. 66, n. 3, p. 257-259, 2001.

SALOBIR, J. Effect of xylanase alone and in combination with beta glucanase on energy utilisation, nutrient utilisation and intestinal viscosity of broilers fed diets based on two wheat samples. Archiv fur Geflugelkunde, Stuttgart, v. 62, n. 5, p. 209-213, 1998.

SALOBIR, J.; POGORELEC, R.; NOVAK, B.; KOMAN-RAJSP, M.; BOGDANIC, C.; MALENSEK, A.; SALOBIR, K.; ORESNISK, A. The effect of betaglucanase alone and in combination with xylanase on the nutritive value of diets based on barley of low or high viscosity in broiler chickens. Archiv fur Geflugelkunde, Stuttgart, v. 64, n. 5, p. 231-236, 2000. 
SIBBALD, I. R.; SLINGER, S. J. A biological assay for metabolizable energy in poultry feed ingredients together with findings which demonstrate some of problems associated with the evaluation of fats. Poultry Science, Champaign, v. 42, n. 2, p. 313-325, 1963.

SIMS, M. D.; BLAIR, M.; HOOGE, D. M. Live performance, caloric efficiency, carcass characteristics, and cost/gain of broiler chickens fed cornsoy-poultry byproduct diets with or without the enzyme Rovabio ExcelTM. Poultry Science, Champaign, v. 80, p. 168, 2001. Supplement 1.
YU, B.; CHUNG, T. K. Effects of multiple-enzyme mixtures on growth performance of broilers fed cornsoybean meal diets. Journal Applied Poultry Research, Savoy, v. 13, n. 2, p. 178-182, 2004.

ZANELLA, I.; SAKOMURA, N. K.; SILVERSIDES, F. G.; FIGUEIREDO, A.; PACK, M. Effect of enzyme supplementation of broiler diets based on corn and soybeans. Poultry Science, Champaign, v. 78, n. 4, p. 561-568, 1999. 